$\begin{array}{ll} & \text { Etnográfica } \\ \text { etnográfica } & \text { Revista do Centro em Rede de Investigação em }\end{array}$

Antropologia

vol. 25 (2) | 2021

Vol. 25 (2)

\title{
Introduction: getting emotional
}

\section{Maria Cardeira da Silva and Clara Saraiva}

\section{CpenEdition \\ Journals}

\section{Electronic version}

URL: https://journals.openedition.org/etnografica/10384

DOI: 10.4000/etnografica.10384

ISSN: 2182-2891

\section{Publisher}

Centro em Rede de Investigação em Antropologia

\section{Printed version}

Number of pages: 431-435

ISSN: 0873-6561

\section{Electronic reference}

Maria Cardeira da Silva and Clara Saraiva, "Introduction: getting emotional", Etnográfica [Online], vol. 25 (2) | 2021, Online since 29 July 2021, connection on 19 January 2022. URL: http:// journals.openedition.org/etnografica/10384 ; DOI: https://doi.org/10.4000/etnografica.10384

\section{(@) $(1) \Theta$}

Etnográfica is licensed under a Creative Commons Attribution-NonCommercial 4.0 International License. 


\section{Introduction: getting emotional}

\section{Maria Cardeira da Silva and Clara Saraiva}

SILVA, Maria Cardeira da (m.cardeira@fcsh.unl.pt) - CRIA/FCSH-UNL, Portugal

SARAIVA, Clara (maria-saraiva@campus.ul.pt) - CEC/FLUL, Portugal

OVER THE LAST YEARS, AND ENCOMPASSING THE TREND OF THE "emotional turn" in Anthropology (Lutz and White 1986; Leavitt 1996; Wulff 2007; Beatty 2013), research and publication on culture, heritage and emotions have multiplied (Thrift 2004; Crang and Tolia-Kelly 2010; De Nardi 2014 ; Waterton 2014; Crouch 2015; Tolia-Kelly, Waterton and Watson, 2016; Birenboim 2016; Smith, Wetherell and Campbell 2018, among many others).

In fact, the field of heritage studies pioneered this approach in many ways, especially with its forays into critical museography, and since the moment when authors like Kirshenblatt-Gimblett (1998, 2004, 2005) - and later on many others - began to consider the performative dimensions of heritage and ascribed agency to objects and, therefore, their ability to act also upon emotions. Actually we could say that, from this point of view, heritage studies were also in the front line of current perspectives on more-than-human anthropology, and thus interfere in social life.

This has, of course, followed concomitant trends which progressively push visitants, tourists, consumers and citizens in general to cherish and "value" feelings and emotions as educational tools for citizenship under global and national heritage regimes, encompassing the Human Rights Universal regime and the need to accommodate "creative diversity" (UNESCO 1995 [1991]) from the 1990s on.

Stakeholders and management entities of heritage and culture at large soon adapted themselves to this trend and demand. Following that movement, Anthropology of Tourism also incorporated the same trend, valuing feelings and emotions in its approaches (Graburn 2001; Robinson 2012; Robinson and Picard 2012; Salazar 2011; Simoni 2016; etc.). As Bendix (2021) puts it, life is lived in increasingly heterogeneous societies, permeated with technological sensory enhancements and barriers and such realization today very often takes the road of heightened sensory stimulation, as chroniclers and theorists of leisure society attest. Nevertheless, even if heritage and tourism sites are privileged places to analyse these entanglements of emotions, culture practices, politics 
and theory (and commodification of senses and emotions), one needs to look further, to other locations, in order to complexify its predicaments.

In the dossier on "Displaying feelings and emotions in cultural settings" we have gathered four articles that deal with culture and senses, feelings and emotions in different ways and cultural scenarios. The idea for the dossier came up in a conference with the same title held in Lisbon in 2009. The purpose of the conference was then to articulate a series of reflections around different forms of emotions displays in diverse cultural and political stages, in order to analyse its potential for the constitution of "communities of feeling".

While some of the texts refer to ethnographic situations that go in that direction (Maria Cardeira da Silva and Clara Saraiva), Regina Bendix's contribution elegantly addresses the difficulties of articulation between senses and cognition, grasping experiences and sites of interaction where sensations are expressed in a culturally shared fashion: wine tasting, paremiology, apodemicae, birth pain, hunting. She writes about senses, rather than emotions, "as powerful communicators and interpreters between world, body and mind, the senses facilitate pre-emotive, bodily states that are essential for how we feel at a given moment" (Bendix 2021: 518). The question is how to pour the inexpressible into the verbal, especially when anthropologists - like tourists, for instance are logo-centric in their responses. Thinking about emotions inevitably leads us to the limits of the organization of knowledge production and expression which has privileged particular variants of hearing and seeing: "Sensory experience is used far better in the food and wellness industry than in cultural research" (Bendix 2021: 528).

Regina replaces Herzfeld's (1997) idea of "culture intimacy" by that of "interpersonal intimacy". By doing so, she tries to elude culturalist approaches and anchors emotions both on senses (and its biological dimension) and on individual experience. Maria José Fazenda follows the same path, inviting us to the stage of theatrical dance. She states that emotional expression is a dimension of the self that intervenes in the construction of the dance, building on the premise that theatrical dance is a universe of meanings by which people represent their worldviews and simultaneously materialize an experience with several dimensions: the experience of incorporating and sensing the movement - an experience involving cultural meanings for those who dance and those who watch dancing - and the individual experience of the artist, as a person, molded by interpersonal relationships and culturally situated. Her invitation leads us to revisit the piece Still/Here, authored and performed by Bill T. Jones in 1994, which dramatically addresses a relevant topic that informed the experience of many people at that time - one of fear, loss and segregation, but also of hope and solidarity - brought on by HIV and AIDS epidemic.

If Fazenda's contribution is the one addressing the performative dimension of emotions in a more obvious way, all the articles underline the performative 
potential of staging feelings in order to produce ties, either interpersonal or cultural, exploring their differentiated effectiveness with heterogeneous audiences and the handling of the political capital they may generate either through artistic performances or rituals, folklore or heritage displays. But in the cases presented by Saraiva and Cardeira da Silva, audience and authors, public and performers (as well as emotions) follow fluid and non-dichotomic movements.

Clara Saraiva makes use of the terreiros, which refer both to the physical temple and the congregation of initiated and followers of the Afro-Brazilian cults, to explore the contradictions between an alleged freedom of expressing emotions that seems crucial to their expansion in Portugal, and the highly hierarchical initiation rituals, which obey to norms that should not be transgressed in order to improve one's religious career. It seems here that active subjects, sharing a common state of urgency, look for a stage to pour their feelings and emotions. They act either as performers and/or public, given that both are part of the performance which engages humans and non-humans. In fact, in the terreiros, we observe not only an emotional interaction among the individuals, but also between a follower of these religions and his/her orixá (the god/goddess that commands his/her life). The act of incorporating a deity represents an emotional engagement of the inner self, but also of the self in regard to the public performance that the xirê (feast in honour of the orixás) is all about.

In a Durkheimian perception, rituals and religion act on the effervescence of emotions to produce community (which sacralises itself through this process). This was, somehow, embedded on Andersen perception of imagined communities which gave rise to nations. Nation is thus often seen as an emotionally charged object while cosmopolitanism, or universalism, is seen as ideal and cool, as opposed to the hot emotions of nationalism (Turner 2000; Nash 2003). In a more Weberian perspective, we can track some current forms of cosmopolitanism-induced-by-heritage as a form of re-enchantment (or, still, enchantment) of the word. Considering UNESCO as a sort of a metanation, Maria Cardeira da Silva shows us how the current heritage global regime (Bendix, Eggert and Peselmann 2012) infuses emotions into "cold" cosmopolitanism as a way to reconcile its universalist project with the multiple relativisms that shape the world, and as a tool to resolve "political" tensions, in a "cultural" way, and thus create an "international (or rather transnational) imagined community of feelings". By doing so, heritage regimes make use of emotions as "natural" (thus universal), to "naturalize" the idea of culture and community. In the Gorée Island, enshrined as a slavery memorial, visitors often take the stage to express "their" own pain - actually the pain of enslaved ancestors which they incorporate in identical terms of those participating in terreiros sessions - while residents often act as an audience. All of them play their roles, sometimes interspersed, in one stage where anthropologists (often taken / or performing as tourists) may be trapped in his/hers encounters and mixed feelings. 


\section{REFERENCES}

BEATTY, Andrew, 2013, "Current emotion research in anthropology: reporting the field", Emotion Review, 5 (4): 414-422.

BENDIX, Regina F., 2021, "Verbal art and the expression of the inexpressible: making sense of sensory experience”, Etnográfica, 25 (2): 513-538.

BENDIX, Regina F., Aditya EGGERT, and Arnika PESELMANN, 2012, Heritage Regimes and the State. Göttingen: Göttingen University Press.

BIRENBOIM, Amit, 2016, "New approaches to the study of tourist experiences in time and space”, Tourism Geographies, 18 (1): 9-17.

CRANG, Mike, and Divya P. TOLIA-KELLY, 2010, "Nation, race, and affect: senses and sensibilities at national heritage sites", Environment and Planning A, 42 (10): 2315 -2331 .

CROUCH, David, 2015, "Affect, heritage, feeling", in E. Waterton and S. Watson (eds.), The Palgrave Handbook of Contemporary Heritage Research. London: Palgrave Macmillan, 177-187.

DE NARDI, Sarah, 2014, "An embodied approach to Second World War storytelling mementoes: Probing beyond the archival into the corporeality of memories of the resistance", Journal of Material Culture, 19 (4): 443-464.

GRABURN, Nelson, 2001, "Learning to consume: what is heritage and when is it traditional?", in Nezar AlSayya (ed.), Consuming Tradition, Manufacturing Heritage: Global Norms and Urban Forms in the Age of Tourism. New York: Routledge, 68-89.

HALDRUP, Michael, and Jørgen Ole BÆRENHOLDT, 2015, "Heritage as performance", in E. Waterton and S. Watson (eds.), The Palgrave Handbook of Contemporary Heritage Research. London: Palgrave Macmillan, 52-68.

HERZFELD, Michael, 1997, Cultural Intimacy: Social Poetics in the Nation-State. New York: Routledge.

KIRSHENBLATT-GIMBLETT, Barbara, 1998, Destination Culture: Tourism, Museums, and Heritage. Berkeley, Los Angeles and London: University of California Press.

KIRSHENBLATT-GIMBLETT, Barbara, 2004, "Intangible heritage as metacultural production", Museum International, 56 (1-2): 52-65.

KIRSHENBLATT-GIMBLETT, Barbara, 2005, From Ethnology to Heritage: The Role of the Museum. SIEF Keynote, Marseilles, Conference Proceedings.

LEAVITT, John, 1996, "Meaning and feeling in the anthropology of emotions", American Ethnologist, 23 (3): 514-539.

LUTZ, Catherine, and Geoffrey M. WHITE, 1986, "The anthropology of emotions", Annual Review of Anthropology, 15: 405-436.

NASH, Kate, 2003, “Cosmopolitan political community: why does it feel so right?", Constelations, 10 (4): 506-518.

ROBINSON, Mike, 2012, "Beyond Stendhal: emotional worlds or emotional tourists?", Literature \& Aesthetics, 22 (1): 1-19.

ROBINSON, Mike, and David PICARD (eds.), 2012, Emotion in Motion: Tourism, Affect and Transformation. London: Ashgate.

SALAZAR, Noel, 201 1, Envisioning Eden: Mobilizing Imaginaries in Tourism and Beyond. New York: Berghahn.

SIMONI, Valerio, 2016, Tourism and Informal Encounters in Cuba. New York: Berghahn. 
SMITH, Laurajane, Margaret WeTHERELL, and Gary CAMPBELL, 2018, Emotion, Affective Practices, and the Past in the Present. Oxon and New York: Routledge.

THRIFT, Nigel, 2004, "Intensities of feeling: towards a spatial politics of affect", Geograliska Annaler, 86: 57-78.

TOLIA-KELlY, Divya P., Emma WATERTON, and Steve WATSON, 2016, Heritage, Affect and Emotion: Politics, Practices and Infrastructures. London: Routledge.

TURNER, Bryan S., 2000, "Liberal citizenship and cosmopolitan virtue", in Andrew Vandenberg (ed.), Citizenship and Democracy in a Global Era. Houndmills, Basingstoke and Hampshire: Macmillan Press, 18-32.

UNESCO, 1995 [1991], Report of the World Commission on Culture and Development. New York: United Nations.

WATERTON, Emma, 2014, "A more-than-representational understanding of heritage? The 'past' and the politics of affect", Geography Compass, 8 (11): 823-833.

WULFF, Helena (ed.), 2007, The Emotions: A Cultural Reader. London: Berg. 